\title{
Campylobacter mustelae, a New Species Resulting from the Elevation of Campylobacter pylori subsp. mustelae to Species Status
}

\author{
J. G. FOX,${ }^{1}$ TERRY CHILVERS, ${ }^{2}$ C. STEWART GOODWIN,${ }^{2}$ N. S. TAYLOR,${ }^{1}$ PAUL EDMONDS,${ }^{3}$
} LINDSAY I. SLY, ${ }^{4}$ AND DON J. BRENNER ${ }^{5 *}$

\begin{abstract}
Division of Comparative Medicine, Massachusetts Institute of Technology, Cambridge, Massachusetts 02139'; Department of Microbiology, Royal Perth Hospital, Perth, Western Australia 6001, Australia ${ }^{2}$; School of Applied Biology, Georgia Institute of Technology, Atlanta, Georgia 303323 ${ }^{3}$ Department of Microbiology, University of Queensland, St. Lucia, Queensland 4067, Australia ; and Meningitis and Special Pathogens Branch, Division of Bacterial Diseases, Center for Infectious Diseases, Centers for Disease Control, Atlanta, Georgia $30333^{5}$
\end{abstract}

\begin{abstract}
The name Campylobacter pylori subsp. mustelae was recently proposed for strains belonging to the genus Campylobacter that were isolated from the gastric mucosa of ferrets because of the high levels of deoxyribonucleic acid relatedness ( 85 to $100 \%$ ) of these strains to the type strain of Campylobacter pylori. Subsequent deoxyribonucleic acid relatedness studies done independently in three laboratories by three different methods indicate that the original results were in error. Strains isolated from ferrets in the United States, England, and Australia are members of a single species that is substantially different from $C$. pylori (10 to $20 \%$ relatedness at $50^{\circ} \mathrm{C}$ and 3 to $10 \%$ relatedness at $65^{\circ} \mathrm{C}$ as determined by the hydroxyapatite method; less than $10 \%$ relatedness at $65^{\circ} \mathrm{C}$ as determined by the nylon membrane blot method; and 30 to $49 \%$ relatedness at 66 to $68^{\circ} \mathrm{C}$ as determined by the spectrophotometric method). The strains isolated from ferrets also differ from human $C$. pylori strains in their ability to reduce nitrates, their negative leucine arylamidase reaction, their susceptibility to nalidixic acid, and their resistance to cephalothin. The strains from ferrets possess both polar and lateral flagella, whereas only polar flagella have been demonstrated in human $C$. pylori strains. Thus, the strains isolated from ferrets are members of a species that is distinct from $C$. pylori, and we propose elevating $C$. pylori subsp. mustelae to species status as Campylobacter mustelae sp. nov.
\end{abstract}

Campylobacter-like organisms have been isolated from normal and inflamed gastric mucosa of ferrets in the United States, England, Canada, and Australia (3, 4, 14, 16; J. A. Hollingsworth et al., Conference on $C$. pylori Infections, 1987; Goodwin, unpublished data). The isolates from ferrets most closely resemble Campylobacter pylori, but differ from this species in having lateral flagella as well as polar, sheathed flagella, in their ability to reduce nitrates, in their negative leucine arylamidase reaction, in their susceptibility to nalidixic acid, and in their resistance to cephalothin $(3,4)$.

In 1988 deoxyribonucleic acid (DNA) hybridization studies were published (4) indicating that isolates from ferrets in the United States were very highly related to one another and to the type strain of $C$. pylori. Despite the fact that the isolates from ferrets had a different host and different phenotypic characteristics, their genomic relatedness to $C$. pylori allowed these organisms to be classified as a subspecies, Campylobacter pylori subsp. mustelae (4). After this study was accepted for publication, the authors learned from C. S. Goodwin that the level of DNA relatedness of an isolate from an Australian ferret to C. pylori was quite low, indicating that the two organisms are separate species.

This led to an exchange of strains and to the reexamination of the relatedness of $C$. pylori to the strains from ferrets described in this paper. Our results clearly demonstrate that the DNA relatedness results presented by Fox et al. (4) were in error (the responsibility for which is solely that of P.E. and D.J.B.) and that the isolates from ferrets represent a new species, for which the name Campylobacter mustelae is proposed.

\footnotetext{
* Corresponding author.
}

\section{MATERIALS AND METHODS}

Bacterial strains. C. pylori NCTC 11637 is the original culture of the type strain (= ATCC 43504) and was isolated from a human at Royal Perth Hospital in 1982. C. mustelae NCTC 12032 was isolated from a ferret in England and was obtained from the National Collection of Type Cultures, London, England. C. mustelae 15896 was isolated from a ferret in Western Australia. These strains were cultured on brain heart infusion agar containing $7 \%$ saponin-lysed horse blood and were incubated at $37^{\circ} \mathrm{C}$ for 2 to 3 days in vented jars containing a microaerophilic atmosphere $\left(6 \% \mathrm{O}_{2}, 10 \%\right.$ $\mathrm{CO}_{2}, 84 \% \mathrm{~N}_{2}$ ). Isolates were stored at $-70^{\circ} \mathrm{C}$ in peptone water containing $10 \%$ glycerol. All other strains were isolated in the United States and were cultivated as previously described (4).

DNA base composition. DNA base composition was determined by two modifications of the thermal denaturation method. The method used in the United States has been described previously (4). In Australia, DNAs were extracted by the Marmur method (10), with the addition of protease treatments after cell lysis by sodium dodecyl sulfate and again after ribonuclease treatment (1). The guanine-pluscytosine $(\mathrm{G}+\mathrm{C})$ values were determined by the $T_{i}$ method of Sly et al. (15), using a model 2600 microprocessor-controlled spectrophotometer fitted with a thermal programmer (Gilford Instrument Laboratories, Inc., Oberlin, Ohio).

DNA hybridization. DNA hybridization was done by three methods. The hydroxyapatite method (method 1 ) and the use of thermal elution profiles to determine divergence within related DNA sequences were done in the United States as described previously (4).

The nylon filter blot method (method 2) was used in Perth, 
TABLE 1. DNA relatedness of $C$. mustelae and $C$. pylori

\begin{tabular}{|c|c|c|c|c|c|c|c|c|c|c|c|c|c|}
\hline \multirow{4}{*}{ Test strain } & \multicolumn{13}{|c|}{ Reference strain } \\
\hline & \multirow{2}{*}{\multicolumn{3}{|c|}{$\begin{array}{c}\text { C. pyiori ATCC } \\
43504^{\mathrm{T}}: \text { method } 1^{a}\end{array}$}} & \multirow{2}{*}{\multicolumn{2}{|c|}{ C. pylori NCTC $11637^{\mathrm{T}}$}} & \multicolumn{4}{|c|}{ C. mustelae ATCC $43772^{\mathrm{T}}$} & \multicolumn{4}{|c|}{ C. mustelae NCTC 12032} \\
\hline & & & & & & \multicolumn{3}{|c|}{ Method $1^{a}$} & \multirow{2}{*}{$\begin{array}{l}\text { Method 2: } \% \\
\text { binding at } \\
65^{\circ} \mathrm{C}^{b}\end{array}$} & \multicolumn{3}{|c|}{ Method $1^{a}$} & \multirow{2}{*}{$\begin{array}{l}\text { Method 3: \% } \\
\text { relatedness } \\
\text { at } 68^{\circ} \mathrm{C}^{\mathrm{c}}\end{array}$} \\
\hline & $\begin{array}{c}\% \\
\text { Binding } \\
\text { at } 50^{\circ} \mathrm{C}\end{array}$ & $\begin{array}{c}\mathrm{D} \\
(\%)\end{array}$ & $\begin{array}{c}\% \\
\text { Binding } \\
\text { at } 65^{\circ} \mathrm{C}\end{array}$ & $\begin{array}{l}\text { Method 2: } \\
\% \text { binding } \\
\text { at } 65^{\circ} \mathrm{C}^{b}\end{array}$ & $\begin{array}{c}\text { Method 3:\% } \\
\text { relatedness } \\
\text { at } 66^{\circ} \mathrm{C}^{c}\end{array}$ & $\begin{array}{l}\% \\
\text { Binding } \\
\text { at } 50^{\circ} \mathrm{C}\end{array}$ & D & $\begin{array}{c}\% \\
\text { Binding } \\
\text { at } 65^{\circ} \mathrm{C}\end{array}$ & & $\begin{array}{c}\% \\
\text { Binding } \\
\text { at } 50^{\circ} \mathrm{C}\end{array}$ & $\underset{(\%)}{\mathrm{D}}$ & $\begin{array}{c}\% \\
\text { Binding } \\
\text { at } 65^{\circ} \mathrm{C}\end{array}$ & \\
\hline C. pylori ATCC $43504^{\mathrm{T}}$ & 100 & 0.0 & 100 & & & 13 & & 6 & & 16 & 25.0 & 5 & \\
\hline C. pylori NCTC $11637^{\mathrm{T}}$ & & & & 100 & 100 & & & & 2 & & & & 49 \\
\hline C. mustelae ATCC $43772^{\mathrm{T}}$ & 10 & 25.0 & 3 & 7 & 30 & 100 & 0.0 & 100 & 100 & 90 & 0.0 & 92 & \\
\hline C. mustelae NCTC 12032 & 12 & 25.5 & 4 & 1 & 44 & 98 & 0.0 & 100 & 75 & 100 & 0.0 & 100 & 100 \\
\hline C. mustelae 15896 & & & & 8 & & 94 & 0.5 & 83 & 96 & & & & \\
\hline C. mustelae R85-13-11 & 12 & 25.0 & 3 & & & 94 & 0.0 & 92 & & 98 & 1.0 & 98 & \\
\hline C. mustelae R85-13-12 & & & & & & 100 & 0.0 & 100 & & & & & \\
\hline
\end{tabular}

"Hydroxyapatite method. D, Divergence within related sequences, calculated to the nearest $0.5 \%$.

b Filter blot method.

c Spectrophotometric method.

Australia. DNA was extracted and purified as described by Majewski and Goodwin (9), except that cells were harvested from plates rather than broth cultures, and the DNA solutions were treated with ribonuclease $A(50 \mu \mathrm{g} / \mathrm{ml})$ at $37^{\circ} \mathrm{C}$ for $30 \mathrm{~min}$ and reprecipitated. DNA pellets were dissolved in TE buffer [ $10 \mathrm{mM}$ tris (hydroxymethyl)aminomethane chloride, $1 \mathrm{mM}$ ethylenediaminetetraacetate, $\mathrm{pH} \mathrm{8.0]}$ to an absorbance at $260 \mathrm{~nm}$ of approximately 0.7 . The solutions were then sonicated for $5 \mathrm{~min}$ at $40 \mathrm{kHz}$ to obtain DNA fragments that were 0.5 to 1.0 kilobases long. All DNA concentrations were then adjusted to an absorbance at $260 \mathrm{~nm}$ of 0.5 . Samples were denatured by boiling and blotted in triplicate onto a positively charged nylon membrane (Biotrace; Gelman Sciences, Inc., Ann Arbor, Mich.) with the aid of a vacuum manifold. Each blot contained $0.5 \mu \mathrm{g}$ of DNA. The membranes were baked at $80^{\circ} \mathrm{C}$ for 1 to $2 \mathrm{~h}$ to immobilize the DNA. Portions (50 ng) of DNA from C. pylori NCTC $11637^{\mathrm{T}}$ ( $\mathrm{T}=$ type strain) and $C$. mustelae ATCC $43772^{\mathrm{T}}$ and NCTC 12032 were labeled with $\left[\alpha-{ }^{32} \mathrm{P}\right]$ cytidine triphosphate by random priming, using a commercial kit (Multiprime; Amersham International plc, Buckinghamshire, United Kingdom) according to the directions of the manufacturer. Nylon membranes were sealed in plastic bags; prehybridization and hybridization were done at $65^{\circ} \mathrm{C}$ in a shaking water bath. Membranes were prehybridized for $1 \mathrm{~h}$ in 3 to $5 \mathrm{ml}$ of hybridization fluid containing $1.5 \times \operatorname{SSPE}(3.6 \mathrm{M} \mathrm{NaCl}, 0.2$ $\mathrm{M}$ sodium phosphate, $0.02 \mathrm{M}$ ethylenediaminetetraacetate, $\mathrm{pH} 7.7), 1 \%$ sodium dodecyl sulfate, $0.5 \%$ nonfat milk powder, $10 \%$ dextran sulfate, and $0.5 \mathrm{mg}$ of denatured salmon sperm DNA per ml. For hybridization the prehybridization fluid was removed and replaced with 3 to $5 \mathrm{ml}$ of the same fluid containing $10 \mathrm{ng}$ of labeled DNA per ml, and the preparations were incubated overnight. After incubation the membranes were removed from the bags and washed at $65^{\circ} \mathrm{C}$ once for $15 \mathrm{~min}$ in $2 \times \mathrm{SSC}$ ( $3 \mathrm{M} \mathrm{NaCl}$ plus $0.3 \mathrm{M}$ sodium citrate), twice for $15 \mathrm{~min}$ in $2 \times$ SSC containing $0.1 \%$ sodium dodecyl sulfate, and twice for $15 \mathrm{~min}$ in $0.1 \times$ SSC containing $0.1 \%$ sodium dodecyl sulfate. The membranes were then air dried and autoradiographed. Radioactivity was assayed by dividing the membranes into $1-\mathrm{cm}^{2}$ pieces, each containing one DNA blot. These were placed into glass vials and dissolved by adding $1 \mathrm{ml}$ of concentrated formic acid. A 9-ml portion of scintillation fluid (Instagel; Packard Instrument Co., Inc., Downers Grove, Ill.) was added to each vial, which was then counted in a liquid scintillation counter (model 1219; LKB Instruments, Inc., Bromma, Sweden). A homologous control reaction (labeled and unlabeled DNAs from the same strain) was used to represent $100 \%$ relatedness.

The spectrophotometric renaturation rate method (method 3, used in Queensland, Australia) for DNA hybridization was performed as described by De Ley et al. (2) and modified by Huss et al. (7). The optimal temperatures for renaturation were calculated by using the method of Gillis et al. (5) to be $68^{\circ} \mathrm{C}$ for $C$. mustelae NCTC 12032 and $66^{\circ} \mathrm{C}$ for C. pylori NCTC $11637^{\mathrm{T}}$.

\section{RESULTS}

DNA base composition. $\mathrm{G}+\mathrm{C}$ contents were determined spectrophotometrically for $C$. mustelae strains both in Australia and in the United States. The $\mathrm{G}+\mathrm{C}$ content of strain ATCC $43772^{\mathrm{T}}$ was calculated to be $39 \mathrm{~mol} \%$ in the United States and $37 \mathrm{~mol} \%$ in Australia. Strain R85-13-11 had a $\mathrm{G}+\mathrm{C}$ content of $42 \mathrm{~mol} \%$ (United States). The $\mathrm{G}+\mathrm{C}$ content of strain NCTC 12032 was calculated to be 40 and $41 \mathrm{~mol} \%$ in the United States and Australia, respectively, and the $\mathrm{G}+\mathrm{C}$ content of strain 15896 was calculated to be 40 and 36 mol\% in the United States and Australia, respectively.

DNA hybridization. Hydroxyapatite, filter blot, and spectrophotometric DNA hybridization methods were used to determine the levels of DNA relatedness of the isolates from ferrets to one another and to $C$. pylori (Table 1 ). In $50^{\circ} \mathrm{C}$ hydroxyapatite reactions the isolates from ferrets were 90 to $100 \%$ interrelated, with 0 to $1 \%$ divergence within the related sequences. The isolates from ferrets were 10 to $16 \%$ related to the type strain of $C$. pylori, with $25 \%$ divergence within the related sequences. In $65^{\circ} \mathrm{C}$ hydroxyapatite and filter blot reactions the isolates from ferrets were 75 to $100 \%$ interrelated and showed 2 to $8 \%$ relatedness to $C$. pylori. As determined by the spectrophotometric method at 66 or $68^{\circ} \mathrm{C}$, C. pylori was 30 to $49 \%$ related to the isolates from ferrets.

\section{DISCUSSION}

Isolates obtained from normal and inflamed gastric mucosa of ferrets in the United States were recently classified as a subspecies of $C$. pylori on the basis of high levels of DNA relatedness to the type strain of $C$. pylori (4). In our study these experiments were repeated and extended by using three hybridization methods, new preparations of DNA, and additional isolates from ferrets. Our results con- 
firm that the isolates from ferrets from the United States are a single species and establish that isolates from ferrets in England and Australia belong to this species.

Our results contradict the previous observation that the isolates from ferrets belong in the species $C$. pylori because they were clearly distinguishable from $C$. pylori. The isolates from ferrets were $16 \%$ or less related to $C$. pylori as determined by the hydroxyapatite and filter blot methods. $C$. pylori and the isolates from ferrets appeared to be substantially more closely related when the spectrophotometric method was used, but were still recognizable as different species. Spectrophotometric method data have been reported to correlate well with membrane filter method data at levels of relatedness above $80 \%$, but are unreliable at levels below $30 \%$ (7).

We (D.J.B. and P.E.) do not know the source of the error in the original experiments (4), but it was most likely due to a contaminated DNA preparation from $C$. pylori type strain ATCC 43504. The taxonomic changes required by the present, corrected data are correction of the emended description of $C$. pylori, elevation of $C$. pylori subsp. mustelae to species rank, and abolition of $C$. pylori subsp. pylori. The first two of these changes are made below, and the third will occur without formal action.

Emended description of Campylobacter pylori (Marshall, Royce, Annear, Goodwin, Pearman, Warren, and Armstrong 1984) Marshall and Goodwin 1987; Fox, Taylor, Edmonds, and Brenner 1988. Fastidious, gram-negative, oxidase-positive, microaerophilic, nonencapsulated, curved rods. Cells are 2.5 to $5 \mu \mathrm{m}$ long and 0.5 to $1.0 \mu \mathrm{m}$ wide with a spiral periodicity (11). Darting motility by means of multiple sheathed unipolar flagella with terminal bulbs. Slow growth in brain heart infusion broth and other liquid media unless shaken. Grows within 2 to 5 days on brain heart infusion agar, blood agar, and chocolate agar. Colonies are nonpigmented, translucent, and 1 to $2 \mathrm{~mm}$ in diameter (11-13). Optimal growth at $37^{\circ} \mathrm{C}$; growth at $30^{\circ} \mathrm{C}$, but not at $25^{\circ} \mathrm{C}$; variable growth at $42^{\circ} \mathrm{C}$. Growth in air enriched with $10 \%$ $\mathrm{CO}_{2}$, but no growth anaerobically. No growth in the presence of $3 \% \mathrm{NaCl}$ or $1 \%$ glycine. Grows in the presence of $0.5 \%$ glycine and $0.04 \%$ triphenyltetrazolium chloride. Catalase positive. $\mathrm{H}_{2} \mathrm{~S}$ production is negative on triple sugar iron agar and variable on lead acetate paper. Urea is rapidly hydrolyzed. Does not reduce nitrates or hydrolyze hippurate. Exhibits leucine arylamidase, alkaline phosphatase, and gamma-glutamyltranspeptidase activities. Susceptible to ampicillin, amoxicillin, cephalothin, erythromycin, gentamicin, kanamycin, penicillin, rifampin, and tetracycline $(6,8$, 11). Resistant to sulfonamides, trimethoprim, and vancomycin $(6,7)$. Variable resistance to nalidixic acid and polymyxin $(6,7)$.

Isolated from the gastric mucosa of humans. Found in cases of gastritis and gastric and duodenal ulcers. Causative agent of type B gastritis, but a role in gastric and duodenal ulcers has not yet been established.

The $\mathrm{G}+\mathrm{C}$ content is 36 to $38 \mathrm{~mol} \%$. The type strain is Royal Perth Hospital isolate 13487 ( = NCTC $11637=$ ATCC 43504), which has a $\mathrm{G}+\mathrm{C}$ content of $37 \mathrm{~mol} \%$.

Description of Campylobacter mustelae sp. nov. Campylobacter mustelae (mus. tel' ae. L. gen. n. mustelae, of a ferret). The description is the same as that given previously for $C$. pylori subsp. mustelae (4). The characteristics are similar to those of $C$. pylori except as noted below. Multiple lateral flagella, as well as polar sheathed flagella with terminal bulbs. Growth at $42^{\circ} \mathrm{C}$. No growth in air enriched with
$10 \% \mathrm{CO}_{2}$, but grows anaerobically with $\mathrm{CO}_{2}$. Reduces nitrates. Does not exhibit leucine arylamidase activity. Susceptible to nalidixic acid $(30 \mu \mathrm{g})$ and resistant to cephalothin (30 $\mu \mathrm{g})(4)$.

Isolated from the normal or inflamed gastric mucosa of ferrets.

The $G+C$ content is 36 to $41 \mathrm{~mol} \%$.

The type strain is strain R85-13-6 (= ATCC 43772); it has a $\mathrm{G}+\mathrm{C}$ content of 37 to $39 \mathrm{~mol} \%$. The characteristics of the type strain are the same as those of the species (4).

\section{ACKNOWLEDGMENTS}

We thank V. Arunpairojana, Julian Cox, John Bowman, and Bill Harper for excellent technical assistance.

\section{LITERATURE CITED}

1. Blackall, L. L., A. C. Hayward, and L. I. Sly. 1985. Cellulolytic and dextranolytic gram-negative bacteria: revival of the genus Cellovibrio. J. Appl. Bacteriol. 59:81-97.

2. De Ley, J., H. Cattoir, and A. Reynaerts. 1970. The quantitative measurement of DNA hybridization from renaturation rates. Eur. J. Biochem. 12:133-142.

3. Fox, J. G., B. M. Edrise, E. B. Cabot, C. Beaucage, J. C. Murphy, and K. S. Prostak. 1986. Campylobacter-like organisms isolated from gastric mucosa in ferrets. Am. J. Vet. Res. 47:236-239.

4. Fox, J. G., N. S. Taylor, P. Edmonds, and D. J. Brenner. 1988. Campylobacter pylori subsp. mustelae subsp. nov. isolated from the gastric mucosa of ferrets (Mustelae putorius furo), and an emended description of Campylobacter pylori. Int. J. Syst. Bacteriol. 38:367-370.

5. Gillis, M. M., J. De Ley, and M. De Cleene. 1970. The determination of molecular weight of bacterial genome DNA from renaturation rates. Eur. J. Biochem. 12:143-153.

6. Goodwin, C. S., P. Blake, and E. Blincow. 1986. The minimum inhibitory and bactericidal concentrations of antibiotics and anti-uker agents against Campylobacter pyloridis. J. Antimicrob. Chemother. 17:309-314.

7. Huss, V. A. R., H. Festl, and K. H. Schleifer. 1983. Studies on the spectrophotometric determination of DNA hybridisation from renaturation rates. Syst. Appl. Microbiol. 4:184-192.

8. Lambert, T., F. Megraud, G. Gerbaud, and P. Courvalin. 1986 Susceptibility of Campylobacter pyloridis to 20 antimicrobial agents. Antimicrob. Agents Chemother. 30:510-511.

9. Majewski, S. I. H., and C. S. Goodwin. 1988. Restriction endonuclease analysis of the genome of Campylobacter pylori with a rapid extraction method: evidence for considerable genomic variation. J. Infect. Dis. 157:465-471.

10. Marmur, J. 1961. A procedure for the isolation of deoxyribonucleic acid from micro-organisms. J. Mol. Biol. 3:208-218.

11. Marshall, B. J., and C. S. Goodwin. 1987. Revised nomenclature of Campylobacter pyloridis. Int. J. Syst. Bacteriol. 37:68.

12. Marshall, B. J., D. B. McGechie, P. A. Rogers, and R. J. Glancy. 1985. Pyloric campylobacter infection and gastroduodenal disease. Med. J. Aust. 142:439-444.

13. Marshall, B. J., H. Royce, D. I. Annear, C. S. Goodwin, J. W. Pearman, J. R. Warren, and J. A. Armstrong. 1984. Original isolation of Campylobacter pyloridis from human gastric mucosa. Microbios Lett. 25:83-88.

14. Rathbone, B. J., A. P. West, J. I. Wyatt, A. W. Johnson, D. S. Tompkins, and R. V. Heatley. 1986. Campylobacter pyloridis, urease, and gastric ulcers, Lancet i:400-401.

15. Sly, L. I., L. L. Blackall, P. C. Kraat, T.-S. Tao, and V. Sangkhobol. 1986. The use of second derivative plots for the determination of mol\% guanine plus cytosine of DNA by the thermal denaturation method. J. Microbiol. Methods 5:139-156.

16. Tompkins, D. S., J. I. Wyatt, B. J. Rathbone, and A. P. West. 1988. The characterization and pathological significance of gastric campylobacter-like organisms in the ferret: a model for chronic gastritis? Epidemiol. Infect. 101:269-278. 